\title{
Sharia Bank Marketing Communication Strategies in Increasing Brand Awareness (Study on Islamic Bank in Yogyakarta City)
}

DOI 10.18196/AlIJS.2020.0122.228-248

\section{SYARIF AS'AD}

syarif_asad@umy.ac.id

Universitas Muhammadiyah Yogyakarta

\begin{abstract}
Building brand awareness in the community is an essential task of a marketing agent. With increased brand awareness, companies can easily create consumer loyalty, which leads to profits from the company. This study aims to describe the pattern of marketing communication strategies that have been carried out by the management of Islamic banks in the city of Yogyakarta in order to increase the brand awareness of the people of the city of Yogyakarta. The informants of this study were 35 employees from 11 Islamic banks in the city of Yogyakarta and the banking supervisor (OJK), using purposive and snowball sampling techniques through structured interviews and questionnaires. The results of this study describe the marketing communication strategy of Islamic banking carried out to reach the layers of society in the city of Yogyakarta through location-based mapping, which includes shopping centers, office complexes, housing, educational institutions, tourist objects, restaurants, around places of worship, and other crowd centers. Other forms of mapping are based on socio-religious organizations such as Muhammadiyah and Nahdlotul Ulama and economic class. In addition, this study also examines the integrated marketing communication strategy that has been implemented by Islamic banks in the city of Yogyakarta through advertisements, sales promos, events and experiences, public relations and publicity, direct marketing, interactive marketing, word of mouth, and personal selling with the aim of achieving brand awareness.

Keywords: Marketing Communication, Islamic Bank, Brand Awareness, Yogyakarta
\end{abstract}

\section{INTRODUCTIONS}

Communication, as an inseparable part of everyday life, makes it everyone's 
primary need. Communication does not only function towards humans as individuals but also as groups or companies. It is similar to communication companies functioned in the business world to provide information to consumers about various things that are inherent in the products and services offered by the company. Priansa emphasizes that other functions of communication in business are very diverse and varied, including; can be a function of socialization, motivation, a form of culture, entertainment, integration, and innovation. ${ }^{1}$ This is an affirmation that communication in business has a significant value that will encourage increasing brand equity. Chinomona explains that advertising professionals in business companies carry out brand communication not only to build brand recognition but also to build a good reputation and a set of standards that companies must maintain or exceed. ${ }^{2}$

Terence states that marketing communication is an important aspect of the overall marketing mission of a company and a major determinant of the company's success or failure, including the marketing communication programs carried out between business to consumer (B2C), business-to-business (B2B) and marketing communication programs aimed at both individual and business customers (integrated). ${ }^{3}$ Berezan and friends explained that about \$ 48 billion per year in US companies spend on marketing communications in order to increase customer loyalty. ${ }^{4}$ This needs to be a significant concern for Islamic Bank (iB) as a sharia-based financial service company that has a big challenge in competing with interest-based banks (conventional) in brand placement, advertising, promotion, sales, and so on.

In line with the development of Islamic banking in Indonesia, Deden Firman Hendarsyah as reported by Wartakota.com revealed; users of Islamic banking products and services have even reached more than 22 million customers. ${ }^{5}$ In other words, the Indonesian people have started to interact with Islamic financial services massively and intently. The growth in the number of customers from 2016 to 2017 increased by 20 percent in accordance with the Financial Services Authority (OJK) target of 10-20 percent. The positive impact that accompanies it is a growth in assets (6.57 percent), total financing (7.92), and third party funds reaching 10.59 percent. ${ }^{6}$ Although this can help build a product image in the eyes of the public in recognizing Islamic bank products more broadly, various marketing communication strategies through various media are imperative to maintain brand awareness in creating greater brand equity.

Until now, the challenge that must be anticipated by Islamic banks in 


\section{$230 \mid$ serew}

Indonesia is the development of digital marketing that must not be underestimated, because the fast and unlimited marketing competition encourages competitors to do everything they can to seize the market, while Islamic banks are still in the stage of forming. and developing markets. How to package effective marketing, carry out promotional cost efficiency, design business strategies that must be in accordance with the ethics and basic principles of doing Islamic business while still upholding the value of honesty as a basic principle of doing business which illustrates that trust must be maintained under any circumstances is a hard effort still needs to be done continuously by Islamic banking. ${ }^{\text {? }}$

Yulianto states that the information systems and partnerships that are mostly built by Islamic banks in Indonesia as a form of commitment are to prioritize the traditional values of silaturrahim as a form of emotional closeness, positioning oneself as part of the environment, culture, religion or emotional closeness to the Muslim community because Islam is the majority religion. ${ }^{8}$ Sultan explains that the quality of the good relationships built by companies to their consumers makes consumers feel disadvantaged if they switch to using services from other companies. ${ }^{9}$ From this reason, it can be said that relationship marketing must be built by companies in order to increase brand awareness which leads to customer loyalty. Relationship marketing is defined as all marketing activities that are directed at building, developing, and maintaining relationships with consumers. ${ }^{10}$

For this reason, Islamic banks must develop appropriate strategies in implementing effective communication with the aim of not wasting marketing costs but being able to reach and convince potential customers or wider consumers. This is because the obstacles faced by Islamic banks with office networks are limited to urban areas and have not reached all levels of society demanding a more precise marketing strategy, however, urban communities as a potential market still need to be reached by Islamic banking through targeted information media. thorough.

Seeing the potential for people in urban areas who are fast in obtaining information, of course it is a very big opportunity for Islamic banking in marketing its products and services to the public. However, this golden opportunity has not been fully utilized by Islamic banking. This can be seen from the minimal quantity of Islamic bank users. The market share that has not reached $6 \%$ of the total market share of the national banking industry indicates that efforts to increase the market share of Islamic banks have reached 
a dead end. The system and number of service offices that are not as good as conventional banks are indicators of the slow growth of Islamic banks in Indonesia. Not to mention the added switching costs created by conventional banks, making people reluctant to switch to Islamic banks. On the other hand, a study by McKinsey shows that in 2030, the need for savings and investment is at the top in terms of the needs of the Indonesian people that year. ${ }^{11}$ This result is certainly an opportunity as well as a challenge for Islamic banks to attract new customers and compete with conventional banks and foreign banks. For this reason, Islamic banking must prepare a strategy in marketing its products and services in order to market its products to the public as a whole. ${ }^{12}$

Since the establishment of Bank Muamalat which is the first Islamic bank in Indonesia, the strategy that has always been used by Islamic banks is the economic rent of the majority of Indonesians who are Muslim. ${ }^{13}$ However, this strategy is deemed ineffective, seeing that there are still many Indonesians who have not used Islamic banks. The factors of price, service, and other advantages still dominate people's interest in connecting and engaging with a bank, when compared to the halal-haram factor of a bank. Several previous studies Özkan and friends, ${ }^{14}$ Shankar and Jebarajakirthy, ${ }^{15}{ }^{\text {Ishak }}{ }^{16}$ Makanyeza and Chikazhe ${ }^{17}$ have proven that the quality of banking services has a positive effect on customer loyalty. For this reason, Islamic banks must pay attention to their marketing myopia so that the implementation of the designed strategy can run as expected.

To create a building brand entity (brand equity), one of the strategies of Islamic banks to compete is to create brand awareness. Brand awareness has been researched by Ewita $^{3} \mathrm{a}$ and friends, ${ }^{18}$ Oppong and Phiri, ${ }^{19}$ Porral and Lang, ${ }^{20}$ which have been shown to increase consumer purchase intention, brand equity and increase loyalty. Moreover, seeing the high professionalism of conventional bank work in several regions in Indonesia Palilati said that Islamic banks must work extra extra in building brand awareness to create strong brand equity. ${ }^{21}$ For this reason, the purpose of this study is to describe the pattern of marketing communication strategies that have been carried out by the management of Islamic banks in the city of Yogyakarta in order to increase brand awareness of Islamic banks.

\section{THEORETICAL FRAMEWORKS}

One of the main elements in marketing is increasing brand equity. Islamic 
banking marketing is carried out to meet customer needs for comprehensive information integration about Islamic banks as Islamic sharia-based financial services business companies to as companies that develop environmental and social developments. The complexity of Islamic banking brand equity requires a strong sustainability marketing plan, by fulfilling all elements of equity proportionally in order to achieve the company's goals. Consumers are not aware of the existence of Islamic banks, which will have an impact on stagnation and even decline in terms of brand image, especially when the marketing challenges faced are very tough to do branding with information technology that is rapidly changing, then the pattern needed is adjusted to these changes ${ }^{22}$ or the term used by Peter F. Drucker in Asnawi and Fanani is an information wave, ${ }^{23}$ while Kertajaya and Sula proposed the term new wave marketing which mentions the pillar of the internet as a foundation in modern marketing currently. ${ }^{24}$

\section{Brand Equity}

Components in marketing - namely products, retail outlets, services and even geographic locations such as cities, regions, or nations - that are referred to as marketing entities will be accepted or created when there is identification of names, terms, symbols, designs, or a combination of these elements. Terence illustrates that the concept of brand equity in addition to being based on the customer perspective also emphasizes how companies need to have an internal perspective as a consideration in influencing company and customer behavior. Brand equity itself can increase because of the high quality of a product so that it can provide satisfaction to the users of the product. High brand equity of a product indicates the company's success in promoting a product to the public. ${ }^{25}$

The most popular definition of brand equity is Aaker's version with its statement that brand equity is "a series of brand assets and liabilities associated with a brand, its name and symbol, which add or reduce the value that a product or service provides to a company and / or customers of the company"26, meanwhile by Kotler and Keller brand equity is an added value given to products and services which is reflected in how consumers think, feel, and act in relation to brands, prices, and market share, as well as the profitability of the brand for the company. ${ }^{27}$ This definition by Islamic banking can place brand equity as something of value for the internal of the Islamic bank (company-based brand equity) and at the same time for customers (customer- 
based brand equity).

Brand equity for Islamic banking can actually be a superior process in accordance with the foundation in Islamic marketing communication ethics emphasized by the Indonesian Bankers Association (IBI), namely: (1) Qaulan Kariiman (noble words): Islamic bank marketers must say in noble words, avoid words that are despicable, such as mocking, making fun, to hurt the feelings of others, (2) Qaulan Ma'rufan (good words): means talk that is beneficial and causes goodness (maslahat), (3) Qaulan Sadida (straight and true): the word 'sadid' means true, precise, and emphatic sentences, (4) Qaulan Baligha (correct speech): according to Jalaludin Rahmat's expression, He interprets it using words that are effective, right on target, communicative, easy to understand, straight to the point, and not complicated, (5) Qaulan Maysura (words that are easy to understand): words that are easy to understand and easy to digest, (6) Qaulan Layyina (gentle words): does not raise your voice or yell. ${ }^{28}$ Effective Islamic marketing communication at Islamic banks is an inseparable part of the brand equity process, and for customers is the expected value according to sharia principles.

\section{Brand Awareness}

Brand awareness as a knowledge has a scope of discussion about whether a brand's integration comes to mind when consumers think about a particular product category and there is hope when the brand is raised. Kertajaya explains the company's strategy so that the brand can have value in the hearts of customers. First, brand as a product means that consumers need related product associations to serve as brand identity. Second, brand as an organization, meaning that the perspective as an organization is focused on the attributes of Islamic banks, such as product innovation, quality awareness movement, attention to the environment, culture, values, and the company's programs. Third, brand as personality, meaning that personality can connect the emotional bonds of consumers with the benefits received from the brand itself which is used as the basis for the required brand differentiation and good customer relationships. Fourth, brand as a symbol, which means that a strong symbol produces cohesion and structure in the brand identity, customers need the strength of the symbol as an identity and make a brand easier to recognize and mention because it has been structured with good product and brand associations. ${ }^{29}$

Brand awareness is the first step for a company to create a relationship 
between consumers and certain brands. ${ }^{30}$ Brands that consumers always remember and always become consumers' preferences in making purchases are a big advantage for a company. Developing brand awareness means paving the way for a brand to win its recognition among other brands in the market. ${ }^{31}$ Developing brand awareness can be through advertising both through print and electronic media. Several previous studies such as Hashim and friends, ${ }^{32}$ Domazet and friends, ${ }^{33}$ Honka and friends, ${ }^{34}$ Clark and friends, ${ }^{35}$ have confirmed that advertising can affect brand awareness. Brand awareness is defined as the ability of a potential customer to recognize and remember that a certain brand belongs to a certain product category. ${ }^{36}$ Given the importance of brand awareness, it is necessary to be an important concern for Islamic banking.

\section{RESEARCH METHODS}

\section{Informants and Procedures}

This study used a survey method, namely the technique of collecting information by means of questionnaires and interviews. The informants in this study were 35 human resources as actors (practitioners) involved in authority (management) in determining or implementing marketing communications at eleven (11) Islamic banks (BUS, UUS, BPRS) consisting of Bank Muamalat, Bank Syariah Mandiri, Bank Rakyat Indonesia Syariah, Bank BNI Syariah, Bank Syariah Bukopin, Bank Panin Dubai Syariah, BPD DIY syariah, BPRS Bangun Derajat Warga, BPRS Dana Hidayatullah, BPRS Mitra Harmoni Yogyakarta, and BPRS Madina Mandiri Sejahtera. As a resource other than Islamic banks, this research also digs up information through the financial services authority (OJK) in this case as a supervisor of the bank intermediation function as well as an authority in planning and implementing policies on financial literacy and inclusion, in this case it focuses on public awareness of Islamic banking, especially in Yogyakarta city. The average research informant of each selected object was 3 people. The selection of informants was carried out to obtain data from sharia banking business actors (practitioners) regarding the steps and strategies of sharia bank marketing communication carried out, and of course by seeking to extract information in depth, especially on the management of Islamic banking in Yogyakarta City.

Researchers cross-checked the research data by analyzing informants' answers in questionnaires and interviews. From the results of the data validity method, the researcher can match the data between the questionnaire and 
the interview, so that the data presented is reliable data. In addition, the researcher also carried out observation extension techniques to gain credibility of the data in the field. Extension of observations is carried out by visiting / asking back to informants who have been interviewed and new informants to dig deeper about the findings of previous researchers. This is done in order to establish intimacy between the researcher and the informant, so that no information is hidden and the words of the informants are in accordance with perceived perceptions. The validity of the data has been confirmed and then analyzed the data by reducing, presenting and drawing conclusions from the findings. In addition, we also use source triangulation to validate the data in this study.

\section{RESULTS AND DISCUSSIONS}

The results of this study were adapted from the marketing strategy process with four stages, namely strategic situation analysis, preparation of marketing strategies, development of marketing programs, and implementation and control of marketing strategies. This stage is based on the statement by Cravens \& Piercy that marketing strategy is a market-driven process of developing a strategy that considers environmental changes and the need to offer superior customer value, ${ }^{37}$ in other words the view of marketing strategy must pay attention to its basic principles by connecting organizations with the environment and views marketing as a function that has more responsibility than other functions of all business activities or what is known as REACH (Respect, Empathy, Audible, Clarity, Humble). ${ }^{38}$ The steps used in the discussion of this research are descriptive of the results of the survey, interview, and documentation. The data that has been collected is then reduced by compiling the data, unloading the data, and rearranging (grouping) then interpreting it. ${ }^{39}$

\section{Sharia Bank Marketing Information}

Although nowadays information technology is very easy to access and the marketing process is no longer limited by space and time which can be done anywhere and anytime, the fundamental consideration in communicating with customers is how the communication can be managed effectively, including considering aspects of the organizational level and individual levels. The process in marketing communication is always directed at providing feedback to consumers, the more intense the elements of communication 
and communication feedback which carried out continuously, the higher the level of customer loyalty. One alternative effective marketing communication according to Rëklaitis and Pilelienë, ${ }^{40}$ Srivastava and Sharma, ${ }^{41}$ Batra and Keller, ${ }^{42}$ Ibrahim, ${ }^{43}$ is through the internet or social media. The coverage of Islamic banking information is divided into several forms, namely based on location, socio-religious organization, economic class and educational institutions based on strata.

\section{Location}

Islamic banking in the city of Yogyakarta has a very diverse target and market share when seen from the various communication characteristics used according to location. The target locations used include, first, in shopping centers such as traditional markets and malls. Activities carried out jointly by most Islamic banks are by participating in the iB Vaganza expo event organized by OJK and the Indonesian Sharia Bank Association (Asbisindo) or independently. Second, in offices, this is a strategic position for a bank because each office needs banking services to carry out its company operations. In addition, several Islamic banks in the city of Yogyakarta have also collaborated with several universities and schools to serve student tuition payments and payroll for university and school employees. Third, in the housing complex, in line with the high demand for housing for urban communities, Islamic banks also manage the financing aspects related to the provision of shelter by collaborating with housing providers through KPR Syariah.

Fourth, in tourist attraction areas, Islamic banking has the same opportunity as other business institutions or financial institutions in conducting marketing communications, although not all certain locations or segments eventually become the target market. Tourist spots often offer ample opportunities for Islamic banking to carry out information and educational activities through recreational activities seeing Yogyakarta as a center of culture, arts and entertainment. Fifth, in restaurants, restaurants as one of the places that are still frequently used by the public to enjoy culinary offerings, and restaurants with a large enough visitor level are strategic media that can be used as a means of communication between Islamic banking and customers and the wider community. Sixth, around places of worship, forms of marketing communication to sharia banking customers are not always oriented to the business aspect only, but also in social activities around places of worship, including their development. Activities that are usually carried out are training in 
mosque management finance, renovating mosques, worship equipment and carrying out routine recitation activities facilitated by Islamic banking. Seventh in the other center of the crowd, the many big events organized by Asbisindo, OJK, Provincial government, and others provide opportunities for Islamic banks in the city of Yogyakarta to introduce closer and at the same time market products and services owned by Islamic banks with a variety of advantages respectively.

\section{Religious Social Organizations}

For Islamic banking, especially in Indonesia, in establishing closeness with socio-religious organizations such as Muhammadiyah, Nahdlotul Ulama (NU) and Persis, it is a necessity that will encourage closeness with their congregations to efforts to effective marketing communication of Islamic banks. The cooperation between Islamic banking and Muhammadiyah has been carried out through cooperation in education, financing and investment, as well as other financial services for the development of Muhammadiyah Business Charities such as Muhammadiyah Higher Education, Muhammadiyah Hospital, Minimarket Muhammadiyah, Baitul Tamwil Muhammadiyah by Bank Muamalat, Bank Syariah Mandiri, BRI. Syariah, BNI Syariah, Bank Syariah Bukopin, BPD DIY syariah, BPRS BDW, and BPRS Madina. In the Nahdlotul Ulama environment, several collaborations have been carried out in the form of strategic cooperation in the field of activities using Islamic financial products and services by Bank Muamalat, BNI Syariah provides sharia banking services to the Nahdatul Ulama Doctors Association (PDNU) and provides payment services for students at Alma Atta University Yogyakarta.

Apart from Muhammadiyah and Nahdlotul Ulama, religious organizations such as the Islamic Union (Persis) and Al-Irsyad, the Hidayatullah Central Executive Board (DPPH) are among the socio-religious organizations that have also become marketing targets. Marketing is carried out through institutional cooperation in the context of communication and education about Islamic financial products and services that can be accessed by the congregation. Apart from that, Islamic banking in Yogyakarta also collaborates with socio-religious institutions by providing sponsorship in activities such as recitation, birthdays and several other activities.

\section{Economic Class}

A clear mapping of the needs for products and services based on eco- 
nomic class must be done in order to determine the economic (financial) capacity of customers, so that the marketing communications delivered can be adjusted to the segmentation carried out by Islamic banking. Products and services that are provided appropriately according to market segments will be able to reduce financial risk and accelerate customer business growth and have an impact on the financial performance of Islamic banks.

Based on the marketing communication of Islamic banking in the city of Yogyakarta, economic classifications are based on the location and products used, namely the upper class, described as elite housing, elite offices and malls, multi-national companies / entrepreneurs. The products used are commercial products, financing for elite housing and apartment developers, and insurance partnerships. The middle class is described as middle class housing, individual developers, retailers, and shop complexes. The products used are simple retail and housing finance products. Meanwhile, the lower class is described as a group of creative industry entrepreneurs, small economic groups, and traditional markets. The products used are micro products and KUR Syariah, and Qord (hasanah) - without collateral.

\section{Education Level}

Marketing communication certainly considers who the audience and stakeholders will receive the message from the communication so that the purpose of the communication delivered can be received and responded to according to marketing objectives. The accuracy in using various communication indicators that are adjusted to the perceptiveness of each segment with the level of education will help the realization of communication goals. Bank Muamalat BNI Syariah, BS Bukopin, BPD DIY Syariah, BPRS BDW conducted a special mapping by trying to separate customers based on education strata of certain products. This requires communication to be carried out with a different approach to the segments of undergraduate, secondary and basic education. Meanwhile, Panin Syariah Bank, BPRS Mitra Harmoni, and BPRS Madina Syariah carry out a marketing communication pattern that focuses only on certain segments of education strata. For example, Panin Syariah Bank focuses on marketing communication with the secondary and tertiary education strata segment only, BPRS Mitra Harmoni focuses on primary and tertiary education, while BPRS Madina focuses on marketing communication with the target of secondary education strata.

However, this strategy is not absolutely necessary for some Islamic banks 
in conducting marketing communications. Marketing communications can also be carried out by separating them based on education strata whose implementation requires extra strategies and with various extra cost consequences. According to the OJK, for Islamic banks that are growing and developing with various marketing limitations, especially in marketing communications, integrated solutions in marketing communications are highly recommended to overcome the limitations of their very broad marketing reach. Seric and friends explained that marketing communication is not only limited to the advertising field, but can be through public relations, sales promotion, direct marketing, personal selling, sponsorship, and so on. ${ }^{44}$ In addition, the role of social media is also seen as effective in integrating marketing communication. ${ }^{45}$

\section{Determining Media Channels in Marketing Communication}

Mapping the use of communication media which are very numerous, varied, and complex, making the marketing focus of Islamic banking cannot be ruled out. Marketing communication means which are the choice of service businesses, among others; direct marketing, sales promotion, public relations, advertising, sponsorship, personal selling, electronic marketing, word of muth marketing, social media marketing, experiential marketing and others. Of these several strategies, can be combined harmoniously in conducting marketing communications effectively. Foroudi and friends explain that the integration of marketing communications can form brand awareness, brand image, brand positioning, brand reputation and brand identification. ${ }^{46}$

The practice of using communication media found in the field is very diverse and most Islamic banks have tried to implement integrated marketing communication. This is done by combining several marketing tools through media channels to communicate messages such as through direct or indirect advertising. Advertising on mass media still occupies the highest position with an average rate of twice a week through television, radio, print media (newspapers, magazines, brochures), social media (whatsapp, facebook, youtube, instagram, twitter) and the internet (website), this media channel is widely used as an effort to remind the brand (products and services) of Islamic banks. Several other media channels were also carried out by optimizing sales promos through stands, bazaars, exhibitions, and cooperation with other business companies such as special facilities plus discounts for users of the hasanah card (BNI Syariah) at the Dafam Rohan hotel, discounted fees for 
patients using Bank Syariah debit Mandiri at Asri Medical Center UMY.

The large number of major activities in Yogyakarta are often utilized by most Sharia banks by taking part in events and experiences (sponsorship). This can be seen in the anniversary activities of the city of Yogyakarta, the anniversary of the major campuses in Yogyakarta, national scale activities and events held in Yogyakarta, social services, and the commemoration of Islamic holidays. Apart from that, Islamic banking in Yogyakarta is often the main sponsor in activities with Islamic themes such as the Islamic book fair, bazaar and higher education exhibitions.

As an inseparable part of Islamic banking in the Muslim community in Yogyakarta, public relations are well maintained through relationships with the public and aspects of publication (public relations and publicity). Activities carried out by each Islamic bank are milad activities which contain positive activities involving customers and the public in general, these activities include halal product exhibitions, healthy walks, free medical examinations, blood donations, free circumcision, provision of basic foodstuffs, compensation for orphans and the elderly, competitions for kindergarten and elementary school children, and others. Positive branding inherent in Islamic banking can often be conveyed if it is managed properly so that the information can become public consumption and increasingly flows and runs relay from information and invitations from one person to another (word of mouthWOM). Seeing the large number of urban communities who use social media as a lifestyle, electronic word of mouth (e-WOM) is very influential in the formation of brand awareness. ${ }^{47}$

\section{Increasing Islamic Bank Brand Awareness through Market- ing Communication Strategy}

Increasing brand awareness is aimed at building customer awareness of the brand through various elements inherent in Islamic banks. Efforts to achieve brand awareness at both the recognition and recall levels involve two activities, namely: trying to acquire a brand identity and trying to associate it with a particular product class. Therefore, the duration in introducing products and services must always be considered so that brand awareness can be created in the minds of consumers. Langaro and friends say that awareness is created through repeated and memorable consumer exposure to brand elements, such as names, slogans, types of logos, or packaging. ${ }^{48}$ In addition, research by Martin and Strong explains that building consumer trust is impor- 
tant in increasing brand awareness of a product. ${ }^{49}$

As some Islamic banks have done in increasing consumer awareness by designing the message content properly to the market. For example: Bank Muamalat as the pioneer of the first Islamic bank in Indonesia by using the slogan "First Pure Syariah", this is an advantage that is used as message content to the wider community as an inherent identity as an attractive slogan to make it easier for consumers to remember. Meanwhile, Bank Syariah Mandiri likens itself to the sun, which illuminates every morning and brings goodness continuously and gives blessings to the universe, with the message that BSM always contributes to building the country's economy, networks and ATMs throughout the archipelago that continue to grow, capable of serving millions of customer transactions. BNI Syariah with products marketed in the form of funding and lending always inserts the word 'Hasanah' which means kindness, the message that BNI Syariah brings goodness to each product, namely by labeling hasanah on the final name of the product, what BNI Syariah does in this case is giving strong point according to product category, brand or both. Bank Syariah Bukopin instilled the message to Serve with Conscience and Become the Sharia Bank of Choice with the Best Service. A unique message made by BPRS Mitra Harmoni with an invitation to save, deposit and finance by inserting pearls of wisdom, Hadiths, uniquely designed pieces of Al Quran verses.

Delivering messages that are easy to remember by consumers is a determinant of success in making consumers aware of the products offered. A message with a structure, format and source that is unique, special and different, especially when compared to other brands, is an important asset for Islamic banks in creating brand awareness. By having high brand awareness, the company already has a valuable asset, especially in creating consumer trust. This opinion is in line with the findings of Clark and friends which explains that brand awareness and product quality that consumers perceive are assets of a company. ${ }^{50}$

\section{CONCLUSIONS}

Sharia bank marketing communication strategy is carried out to reach layers of society in the city of Yogyakarta. Establish good communication as an effort to increase and also recall to various segments of Islamic banks through location-based mapping which includes shopping centers, office complexes, housing, tourist attractions, restaurants, around places of wor- 
ship, and other crowded centers. The forms of marketing communication for Islamic banks in the city of Yogyakarta are not specifically mapped based on government areas, but are focused on more potential locations, socio-religious organizations such as Muhammadiyah and Nahdlotul Ulama, as well as by economic class. The marketing communication strategy of Islamic banks in the city of Yogyakarta in selecting and determining the media used has been carried out in an integrated manner (Integrated Marketing Communication). In addition, the marketing communication strategy of Islamic banking in increasing public brand awareness in the city of Yogyakarta is still not optimal, even though many efforts have been made to gain brand awareness both in the recognition and recall levels. The weakness in this study is that the marketing methods of banking industry are very likely to occur in common with one another, so that researchers find it difficult to identify specific marketing strategies for each company. Besides that, the second weakness in this study is that data from sharia marketing experts has not been obtained due to the limited access of researchers to expert sources.

\section{MANAGERIAL IMPLICATIONS}

From various dimensions in this research on marketing communication strategies of Islamic banking in the city of Yogyakarta can contribute to managers. First, optimization of marketing communications by Islamic banks needs to be done in order to reach all elements of society and not only limited to customers, so that the reach of marketing communications in increasing brand awareness is not limited. Second, considering that integrated marketing communication has a significant impact on marketing, and Islamic banking is still limited to certain media such as advertising, it will be much more effective and efficient if integrated marketing communications are also carried out on other media channels with a wider reach and more affordable. Third, communication management for old customers is considered to be heavier than new customers, so the marketing communication strategy is carried out proportionally by mapping the customer maintenance field as evidence of the seriousness of increasing and strengthening customer value to achieve levels of satisfaction and loyalty.

\section{ENDNOTES}

1 Doni Priansa, Komunikasi Pemasaran Terpadu Pada Era Media Sosial. Bandung: Pustaka Setia, 2017. 
2 R. Chinomona, "Brand communication, brand image and brand trust as antecedents of brand loyalty in Gauteng Province of South Africa.” Afr. J. Econ. Manag. Stu, vol.7, no.1, pp.124-39. 2016.

3 Terence A, S, Komunikasi Pemasaran Terpadu dalam Periklanan dan Promosi. Jakarta: Salemba Empat, 2014.

4 O. Berezan, Krishen, A. S, S. Tanford, and C. Raab, "Style before substance? Building loyalty through marketing communication congruity. Euro. J. Mark, vol. 51, no.7/8, pp. 1332-1352, 2017.

5 "Nasabah Bank Syariah", Wartakota, akses 17 Maret 2019, https:// wartakota.tribunnews.com/2017/10/07/ternyata-ada-22-juta-nasabah-banksyariah

6 "Market Share Keuangan Syariah Capai 8 Persen", OJK, akses 28 Feb 2019, https://www.ojk.go.id/id/berita-dan-kegiatan/siaran-pers/Pages/Siaran-PersMarket-Share-Keuangan-Syariah-Capai-8-Persen.aspx

7 Y. Orgianus, Moralitas Islam dalam Ekonomi $\mathcal{E}$ Bisnis. Bandung: Marja. 2012.

8 A. Yulianto, "Membangun kemitraan bank syariah dengan pendekatan shariah marketing," vol.19, no. 1, pp. 197, 2011.

9 A. Sultan, Identifying brand touchpoints to increase switching costs in the banking industry. Int. J. Bank. Mark, vol. 38 no. 3, pp. 718 - 736. 2019

10 Morgan, R. M., and Hunt, S. D, "The commitment-trust theory of relationship marketing”. J. Mark, vol. 58, no. 3, pp. 20-38. 1994.

11 McKinsey and Company, The new indonesian consumer, pp. 1-21, 2012.

12 Y. Atsmon, Kuentz, J.-F., and J. Seong, "Building brands in emerging markets," Vol.8. 2012.

13 M. Zakiy, "The Moderating Effect of Switching Cost on The Influence Of Price And Service Quality Towards Switching Intention". (In Third International Conference on Sustainable Innovation 2019-Humanity, Education and Social Sciences). Atlantis Press: 2019.

14 P. Özkan, S. Süer, Keser, Ý. K, and Kocakoç, Ý. D, "The effect of service quality and customer satisfaction on customer loyalty”. Int. J. Bank Marketing, vol. 38(2), pp. 384-405, 2020.

15 A. Shankar, and C. Jebarajakirthy, "The influence of e-banking service quality on customer loyalty. Inter. J. Bank Marketing, vol. 37 no. 5, pp. 1119- 1142, 2019.

16 M.Z. Ishak, and E. P. Azzahroh, "Pengaruh Kualitas Layanan Terhadap Loyalitas Nasabah Bank Syariah Dengan Kepuasan Nasabah Sebagai Variabel Intervening". JEBIS, vol. 3 no. 1, pp. 26-38 2017.

17 C. Makanyeza, and L. Chikazhe, "Mediators of the relationship between service quality and customer loyalty. Inter. J. Bank Marketing, vol. 35, no.3, pp. 540556, 2017.

18 M. Swita3a, W. Gamrot, B. Reformat, and Biliñska-Reformat, K, "The influence of brand awareness and brand image on brand equity-an empirical study of logistics service providers". J Econ and Manag, vol. 33, no. 3, pp. 96-119, 2018. 
19 P. K. Oppong, and M.A. Phiri, "Impact of brand awareness and association on loyalty: the role of equity in plant medicine market in Kumasi, Ghana”, vol. 13, no. 2, 163-181, 2018.

20 C. C. Porral, and M. F. Lang, "Private labels: The role of manufacturer identification, brand loyalty and image on purchase intention." British Food. J, vol. 117, no. 2, pp. 506-522, 2015.

21 A. Palilati, "Pengaruh Nilai Pelanggan Kepuasan Terhadap Loyalitas Nasabah Tabungan Perbankan Di Sulawesi Selatan”. Jurnal Manajemen dan Kewirausahaan, vol. 9, no. 1, pp. 73-81, 2007.

22 S. Scott, and S. Alison, "Unbranding 100 Branding Lessons for the Age of Disruption.” Hoboken: New Jersey, 2018.

23 N. Asnawi, and M. A. Fanani, "Pemasaran Syariah: Teori, Filosofi EO Isu-Isu Kontemporer." Jakarta: Rajawali Press, 2017.

24 H. Kertajaya, and M. S. Sula, "Syariah Marketing." Bandung: Mizan, 2006.

25 Terence A. S, Komunikasi Pemasaran Terpadu dalam Periklanan dan Promosi, Jakarta: Salemba Empat, 2014.

26 D. A. Aaker, "Managing Brand Equity; Capitalizing on the Value of a Brand Name", 1991, Retrieved from https://books.google.co.id.

27 Philip Kotler, and K. L. Keller, Marketing Management, Edition 14, England: Pearson Education, 2012.

28 Ikatan Bankir Indonesia, Strategi Bisnis Bank Syariah, Jakarta: Gramedia Pustaka Utama, 2015.

29 H. Kertajaya, Toursm Marketing 3.0, Jakarta: Gramedia Pustaka Utama, 2013.

30 I. S. Domazet, I. Đokiæ, and O. Milovanov, "The Influence of advertising media on brand awareness," vol. 23(1), pp. 13-22, 2018.

31 R. R. Ahmed, J. Vveinhardt, and D. Streimikiene, "Interactive digital media and impact of customer attitude and technology on brand awareness: evidence from the South Asian countries, vol 18, no. 6, pp. 1115-1134, 2017.

32 N. H. Hashim, Normalini, and N. Sajali, "The Influence Factors Towards Mobile Advertising Message Content on Consumer Purchase Intention”, Glob. Busi. Rev, vol. 19, no. 5, 1187-1206, 2018

33 I. S. Domazet, I. Đokiæ, and O. Milovanov, "The Influence, 2018.

34 E. Honka, A. Hortaçsu, and M. A. Vitorino, "Advertising, consumer awareness, and choice: Evidence from the US banking industry," The RAND J. Econ, vol. 48, no.3, 611-646, 2017.

35 C. R. Clark, U. Doraszelski, and M. Draganska, "The effect of advertising on brand awareness and perceived quality: An empirical investigation using panel data”, Qme, vol. 72, pp. 207-236, 2009.

36 D. A. Aaker, Managing Brand, 1991, Retrieved from https://books.google.co.id.

37 W. Cravens, David, and Piercy, F. Nigel, Strategic Marketing, New York: Mc Graw-Hill International, 2013.

38 Doni Priansa, Komunikasi Pemasaran, 2017.

39 S. Kholifah,and I. W. Suyadnya, Metode Penelitian Kualitatif: Berbagai Pengalaman dari Lapangan. Jakarta: Rajawali Press, 2018. 
K. Rëklaitis, and L. Pilelienë, "Principle differences between B2B and B2C marketing communication processes,” Manag. Org: Sys. Rese, vol. 81, no. 1, pp. 73 86, 2019.

41 D.Srivastava, and R.W. Sharma, "Developing a model for studying the antecedents and effects of Word of Mouth (WoM) and e-WoM marketing based on literature review”, Jindal. J. Busi Rese, vol. 6, no. 1, pp. 25-43, 2017.

42 R. Batra, and K.L. Keller, "Integrating marketing communications: New findings, new lessons, and new ideas", J. Mark, vol. 80, no. 6, pp. 122-145, 2016.

43 Ibrahim, M. (2016). Evaluating hotel websites as a marketing communication channel: A dialogic perspective. Information Development, 32(3), 718-727.

44 M. Seric, I.G. Saura, and J. Mikulic, "Exploring integrated marketing communications, brand awareness, and brand image in hospitality marketing: a crosscultural approach/Istrazivanje integrirane marketinske komunikacije, svjesnosti o marki i imidza marke u marketingu u ugostiteljstvu: kros-kulturalni pristup”, vol. 28(2), pp. 159-172. 2016.

45 R. Batra, and K.L. Keller, "Integrating marketing", 2016.

46 P. Foroudi, K. Dinnie, P. J. Kitchen, T. C. Melewar, and M. M. Foroudi, "IMC antecedents and the consequences of planned brand identity in higher education”, Eur. J. Mark, vol. 51, no. 3, pp. 528-550, 2017.

47 D.Srivastava, and R.W. Sharma, "Developing a model, 2017.

48 D. Langaro, P. Rita, and de Fátima Salgueiro, M, "Do social networking sites contribute for building brands? Evaluating the impact of users' participation on brand awareness and brand attitude”, J. Mark. Comm, vol. 24, no. 2, 146168. 2018.

49 B.A. Martin, and C.S. Strong, "The trustworthy brand: effects of conclusion explicitness and persuasion awareness on consumer judgments”, Mark Lett, vol. 27, no. 3, 473-485, 2016.

50 C. R. Clark, U. Doraszelski, and M. Draganska, "The effect of advertising, 2009.

\section{REFERENCES}

Aaker, D. A. 1991. Managing Brand Equity; Capitalizing on the Value of a Brand Name. Retrieved from: https://books.google.co.id/books?id=r_TSY5sxnO8C\& printsec $=$ frontcover $\&$ dq=inauthor:\%22David + A. + Aaker\%22\&hl-

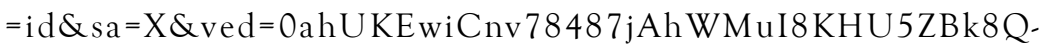
6 AEIKTAA\# $\#_{\mathrm{v}}=$ onepage $\& \mathrm{q} \& \mathrm{f}=$ false

Ahmed, R. R., Vveinhardt, J., \& Streimikiene, D. 2017. Interactive digital media and impact of customer attitude and technology on brand awareness: evidence from the South Asian countries. Journal of Business Economics and Management, 18(6), 1115-1134.

Asnawi, N., \& Fanani, M. A. 2017. Pemasaran Syariah: Teori, Filosofi E⿱ Isu-Isu Kontemporer. Jakarta: Rajawali Press.

Atsmon, Y., Kuentz, J.-F., \& Seong, J. 2012. Building brands in emerging markets. 8. Batra, R., \& Keller, K. L. 2016. Integrating marketing communications: New find- 
ings, new lessons, and new ideas. Joumal of Marketing, 80(6), pp. 122-145.

Berezan, O., Krishen, A. S., Tanford, S., \& Raab, C. 2017. Style before substance? Building loyalty through marketing communication congruity. European Journal of Marketing, 51(7/8), pp. 1332-1352.

Chinomona, R. 2016. Brand communication, brand image and brand trust as antecedents of brand loyalty in Gauteng Province of South Africa. African Journal of Economic and Management Studies, 7(1), pp. 124-39.

Clark, C. R., Doraszelski, U., \& Draganska, M. 2009. The effect of advertising on brand awareness and perceived quality: An empirical investigation using panel data. Qme, 7(2), 207-236.

Cravens, David. W., \& Piercy, Nigel. F. 2013. Strategic Marketing (10th ed.). New York: Mc Graw-Hill International.

Domazet, I. S., Đokiæ, I., \& Milovanov, O. 2018. The Influence of advertising media on brand awareness. Management: Journal of Sustainable Business and Management Solutions in Emerging Economies, 23(1), pp. 13-22.

Foroudi, P., Dinnie, K., Kitchen, P. J., Melewar, T. C., \& Foroudi, M. M. 2017. IMC antecedents and the consequences of planned brand identity in higher education. European Journal of Marketing, 51(3), pp. 528-550.

Hashim, N. H., Normalini, \& Sajali, N. 2018. The Influence Factors Towards Mobile Advertising Message Content on Consumer Purchase Intention. Global Business Review, 19(5), pp. 1187-1206.

Honka, E., Hortaçsu, A., \& Vitorino, M. A. 2017. Advertising, consumer awareness, and choice: Evidence from the US banking industry. The RAND Journal of Economics, 48(3), pp. 611-646.

Ibrahim, M. 2016. Evaluating hotel websites as a marketing communication channel: A dialogic perspective. Information Development, 32(3), pp. 718-727.

Ikatan Bankir Indonesia. 2015. Strategi Bisnis Bank Syariah. Jakarta: Gramedia Pustaka Utama.

Ishak, M. Z., \& Azzahroh, E. P. 2017. Pengaruh Kualitas Layanan Terhadap Loyalitas Nasabah Bank Syariah Dengan Kepuasan Nasabah Sebagai Variabel Intervening. Jurnal Ekonomi dan Bisnis Islam (JEBIS), 3(1), pp. 26-38.

Kertajaya, H., \& Sula, M. S. 2006. Syariah Marketing. Bandung: Mizan.

Kertajaya, H. 2013. Toursm Marketing 3.0. Jakarta: Gramedia Pustaka Utama.

Kholifah, S., \& Suyadnya, I. W. 2018. Metode Penelitian Kualitatif: Berbagai Pengalaman dari Lapangan. Jakarta: Rajawali Press.

Kotler, P., \& Keller, K.L. 2012. Marketing Management, Edition 14, England: Pearson Education

Langaro, D., Rita, P., \& de Fátima Salgueiro, M. 2018. Do social networking sites contribute for building brands? Evaluating the impact of users' participation on brand awareness and brand attitude. Journal of Marketing Communications, 24(2), pp. 146-168.

Makanyeza, C., \& Chikazhe, L. 2017. Mediators of the relationship between service quality and customer loyalty. International Journal of Bank Marketing, 35(3), pp. 540-556. 
Martin, B. A., \& Strong, C. A. 2016. The trustworthy brand: effects of conclusion explicitness and persuasion awareness on consumer judgments. Marketing Letters, 27(3), pp. 473-485.

McKinsey \& Company. 2012. The new indonesian consumer. 1-21.

Morgan, R. M., \& Hunt, S. D. 1994. The commitment-trust theory of relationship marketing. Journal of marketing, 58(3), pp. 20-38.

Oppong, P. K., \& Phiri, M. A. 2018. Impact of brand awareness and association on loyalty: the role of equity in plant medicine market in Kumasi, Ghana. African Journal of Business and Economic Research, 13(2), pp. 163-181.

Orgianus, Y. 2012. Moralitas Islam dalam Ekonomi $\mathcal{E}$ Bisnis. Bandung: Marja.

Özkan, P., Süer, S., Keser, Ý. K., \& Kocakoç, Ý. D. 2020. The effect of service quality and customer satisfaction on customer loyalty. International Journal of Bank Marketing, 38(2), pp. 384-405.

Palilati, A. 2007. Pengaruh Nilai Pelanggan Kepuasan Terhadap Loyalitas Nasabah Tabungan Perbankan Di Sulawesi Selatan. Jurnal Manajemen dan Kewirausahaan, 9(1), pp. 73-81.

Porral, C. C., \& Lang, M. F. 2015. Private labels: The role of manufacturer identification, brand loyalty and image on purchase intention. British Food Journal, 117(2), pp. 506-522.

Priansa, D. J. 2017. Komunikasi Pemasaran Terpadu Pada Era Media Sosial. Bandung: Pustaka Setia.

Rëklaitis, K., \& Pilelienë, L. 2019. Principle differences between B2B and B2C marketing communication processes. Management of Organizations: Systematic Research, 81(1),pp. 73-86.

Scott, S., \& Alison, S. 2018. UnBranding 100 Branding Lessons for the Age of Disruption. Hoboken: New Jersey.

Seric, M., Saura, I. G., \& Mikulic, J. 2016. Exploring integrated marketing communications, brand awareness, and brand image in hospitality marketing: a crosscultural approach/Istrazivanje integrirane marketinske komunikacije, svjesnosti o marki i imidza marke u marketingu u ugostiteljstvu: kros-kulturalni pristup. Market Trziste, 28(2), pp. 159-172.

Shankar, A., \& Jebarajakirthy, C. 2019. The influence of e-banking service quality on customer loyalty. International Journal of Bank Marketing, 37(5), pp. 1119. 1142 .

Srivastava, D., \& Sharma, R. W. 2017. Developing a model for studying the antecedents and effects of Word of Mouth (WoM) and e-WoM marketing based on literature review. Jindal Journal of Business Research, 6(1), pp. 25-43.

Sultan, A. 2019. Identifying brand touchpoints to increase switching costs in the banking industry. International Journal of Bank Marketing, 38(3), pp. 718 - 736.

EEwita ${ }^{3}$ a, M., Gamrot, W., Reformat, B., \& Biliñska-Reformat, K. 2018. The influence of brand awareness and brand image on brand equity-an empirical study of logistics service providers. Journal of Economics $\mathcal{E}$ Management, 33(3), pp. 96 119.

Terence A, S. 2014. Komunikasi Pemasaran Terpadu dalam Periklanan dan Promosi. 
Jakarta: Salemba Empat.

Yulianto, A. 2011. Membangun kemitraan bank syariah dengan pendekatan shariah marketing. Walisongo: Jurnal Penelitian Sosial Keagamaan, 19(1), pp. 197. https:/ /doi.org/10.21580/ws.19.1.218

Zakiy, M. 2019. The Moderating Effect of Switching Cost on The Influence Of Price And Service Quality Towards Switching Intention. In Third International Conference on Sustainable Innovation 2019-Humanity, Education and Social Sciences (IcoSIHESS 2019). Atlantis Press.

https://wartakota.tribunnews.com/2017/10/07/ternyata-ada-22-juta-nasabahbank-syariah

https://www.ojk.go.id/id/berita-dan-kegiatan/siaran-pers/Pages/Siaran-Pers-Market-Share-Keuangan-Syariah-Capai-8-Persen.aspx 